\title{
Metabolism, ATP production and biofilm generation by Staphylococcus epidermidis in either respiratory or fermentative conditions
}

\author{
Ulrik Pedroza-Dávila', Cristina Uribe-Alvarez', Lilia Morales-García', Emilio Espinoza-Simón', \\ Ofelia Méndez-Romero², Adriana Muhlia-Almazán², Natalia Chiquete-Félix ${ }^{1}$ and Salvador Uribe-Carvajal ${ }^{*}$
}

\begin{abstract}
Staphylococcus epidermidis is a Gram-positive saprophytic bacterium found in the microaerobic/anaerobic layers of the skin that becomes a health hazard when it is carried across the skin through punctures or wounds. Pathogenicity is enhanced by the ability of $S$. epidermidis to associate into biofilms, where it avoids attacks by the host and antibiotics. To test the effect of oxygen on metabolism and biofilm generation, cells were cultured at different oxygen concentrations $\left(\left[\mathrm{O}_{2}\right]\right)$. As $\left[\mathrm{O}_{2}\right]$ decreased, S. epidermidis metabolism went from respiratory to fermentative. Remarkably, the rate of growth decreased at low $\left[\mathrm{O}_{2}\right]$ while a high concentration of ATP ([ATP]) was kept. Under hypoxic conditions bacteria associated into biofilms. Aerobic activity sensitized the cell to hydrogen peroxide-mediated damage. In the presence of metabolic inhibitors, biofilm formation decreased. It is suggested that at low $\left[\mathrm{O}_{2}\right] \mathrm{S}$. epidermidis limits its growth and develops the ability to form biofilms.
\end{abstract}

Keywords: Staphylococcus epidermidis, Oxygen concentration, Metabolism, Biofilms, Rate of oxygen consumption, Fermentation

\section{Introduction}

Saprophytic microorganisms control pathogenic bacteria, digest nutrients and synthesize coenzymes, prosthetic groups and amino acids (Foster et al. 2005; Berg 1996; Sender et al. 2016). In the skin, Staphylococcus epidermidis inhibits colonization by Staphylococcus aureus or Streptococcus pyogenes secreting antimicrobial compounds and proteases (Cogen et al. 2010; Iwase et al. 2010). In the skin, S. epidermidis inhabits the epidermis, dermis and the nearly anoxic sebaceous glands (Grice and Segre 2011).

Staphylococcus epidermidis is frequently introduced through wounds and surgical procedures. A recent study reported the presence of antibiotic-resistant

\footnotetext{
*Correspondence: suribe@ifc.unam.mx

1 Department of Genetics and Molecular Biology, Instituto de Fisiología Celular, Universidad Nacional Autónoma de México (UNAM), Mexico City, Mexico

Full list of author information is available at the end of the article
}

S. epidermidis strains in $46 \%$ of hospital secondary infections (Chabi and Momtaz 2019). Many of these strains were resistant to at least three antibiotics (Chabi and Momtaz 2019). Indeed, many antibiotics have to be tested in order to treat $S$. epidermidis nosocomial infections (Roujansky et al. 2020). S. epidermidis is also found frequently in implanted devices such as valves and catheters. There is an active search for materials to coat implant surfaces which may prevent biofilm formation (Rabin et al. 2015). Among these, zirconium nitride has shown promise in orthopaedic implants (Pilz et al. 2019), while sphingosine coating is being used with success on implant titanium-surfaces (Beck et al. 2019). Inside the body, this bacterium has to face attack from the immune system, high $\left[\mathrm{O}_{2}\right]$ (Fang et al. 2016) and antibiotics (Leid 2009), most likely triggering a stress response. Within the organism, $S$. epidermidis may find areas with low $\left[\mathrm{O}_{2}\right]$, similar to its natural habitat; it is likely that the bacterium will make an effort to remain in the hypoxic 
area, adhering to the surface and organizing into biofilms (Lewis 2007; Uribe-Alvarez et al. 2016). In regard to hypoxic environments within the host, these are often found at or near artificial devices such as catheters or prosthetic valves, where biofilms may force removal of implanted devices (Fey and Olson 2010; Büttner et al. 2015).

Understanding the S. epidermidis response to different $\left[\mathrm{O}_{2}\right]$ would help optimize treatments (Cotter et al. 2009). We have reported that growing S. epidermidis at different $\left[\mathrm{O}_{2}\right]$ modifies expression of respiratory chain enzymes and the ability to form biofilms (Uribe-Alvarez et al. 2016). At high $\left[\mathrm{O}_{2}\right]$, cytochrome oxidases and NADH dehydrogenases are abundant and biofilms are minimal. In contrast, $\left[\mathrm{O}_{2}\right]$ depletion increases nitrate reductase expression and association into biofilms (Uribe-Alvarez et al. 2016).

Here, the effect of $\left[\mathrm{O}_{2}\right]$ on both, the aerobic and anaerobic metabolism of $S$. epidermidis was evaluated, together with [ATP]. In addition, the sensitivity of $S$. epidermidis to the toxic effects of hydrogen peroxide was tested. In each case, the biofilm-forming activity of cells was measured (Lewis 2007). When ATP synthesis was inhibited to different degrees by inhibitors of respiration (cyanide) (Uribe-Alvarez et al. 2016) or glycolysis (1,4-bisphosphobutane) (Hartman and Barker 1965; Rosas-Lemus et al. 2016a), biofilm formation also decreased. It is suggested that $S$. epidermidis associates into biofilms as a strategy to avoid high $\left[\mathrm{O}_{2}\right]$.

\section{Materials and methods}

\section{Bacterial strain and growth media}

Staphylococcus epidermidis strain ATCC 12228 was a kind donation from Dr. Juan Carlos Cancino Díaz (Instituto Politécnico Nacional, México). A loophole from the bacterium was suspended in $5 \mathrm{~mL}$ of $3 \%$ tryptic soy broth (Fluka, Sigma) and incubated at $37^{\circ} \mathrm{C}$ for $24 \mathrm{~h}$. Pre-cultures were added to $1 \mathrm{~L} \mathrm{LB}$ medium (1\% tryptone, $0.5 \%$ yeast extract, $1 \% \mathrm{NaCl}$ ) plus $2 \%$ glucose and incubated $24 \mathrm{~h}$ at $30^{\circ} \mathrm{C}$ under aerobic (shaking $150 \mathrm{rpm}$ ), microaerobic $\left(5 \% \mathrm{CO}_{2}\right.$, no agitation) or anaerobic (static in oxygen-depleted sealed acrylic chamber) conditions. Then the cells were washed three times at $5000 \times g$ for $10 \mathrm{~min}$ with distilled water and resuspended in $10 \mathrm{mM}$ HEPES pH 7.4 (Uribe-Alvarez et al. 2016).

\section{Cytoplasmic extracts}

All procedures were conducted at $4{ }^{\circ} \mathrm{C}$. Cells (grown under aerobic, microaerobic or anaerobic conditions) were centrifuged at $5000 \times g$ for $10 \mathrm{~min}$, washed three times with distilled water and resuspended in $50 \mathrm{~mL}$ $10 \mathrm{mM}$ HEPES, $\mathrm{pH}$ 7.4, supplemented with one tablet of protease-inhibitor cocktail (Complete) and $1 \mathrm{mM}$
PMSF. Cells were disrupted by sonication using a Sonics VibraCell sonicator (Sonics \& materials, Inc., Newtown, CT) $7 \times 20 \mathrm{~s}$ with $20 \mathrm{~s}$ intervals. To remove unbroken cells the suspension was centrifuged at $10,000 \times g$ for $10 \mathrm{~min}$ and the supernatant was recovered.

\section{Protein concentration}

Protein concentrations from intact $S$. epidermidis cells were determined by the biuret method (Gornall et al. 1949). Absorbance (540 nm) was measured in a Beckman-Coulter DU50 spectrophotometer. For cytoplasmic extracts, protein concentration was measured by Bradford at $595 \mathrm{~nm}$, using 1 or $2 \mu \mathrm{L}$ aliquots of the sample in a PolarStar Omega (BMG labtech, Ortenberg, Germany) (Bradford 1976).

\section{Rate of oxygen consumption}

The rate of oxygen consumption was measured in $10 \mathrm{mM}$ HEPES $\mathrm{pH}$ 7.4 plus the indicated respiratory substrate. Bacteria, $0.5 \mathrm{mg}$ prot $\mathrm{mL}^{-1}$ were added to a water-jacketed $1 \mathrm{~mL}$ chamber at $37^{\circ} \mathrm{C}$ equipped with a Clark type electrode connected to a Strathkelvin model 782 oxymeter. Data were analyzed using the 782 Oxygen System Software (Warner/Strathkelvin Instruments) (Uribe-Alvarez et al. 2016).

\section{Ethanol production}

Fermentation by cell cytoplasmic extracts $\left(0.5 \mathrm{mg}\right.$ prot. $\left.\mathrm{mL}^{-1}\right)$ was measured in $0.1 \mathrm{M}$ MES-TEA, $\mathrm{pH}$ 7.0, $1.8 \mathrm{mM}$ NAD plus either glucose or glycerol and incubated at $30{ }^{\circ} \mathrm{C}$ for $0,2.5,5$ or $10 \mathrm{~min}$. The reaction was stopped with $30 \%$ TCA, $0.1 \mathrm{~mL}$ and neutralized with $\mathrm{NaOH}$. Ethanol was measured adding a $10 \mu \mathrm{L}$ aliquot $(0.005 \mathrm{mg})$ of the supernatant to $0.2 \mathrm{~mL} 114 \mathrm{mM}$ $\mathrm{K}_{2} \mathrm{HPO}_{4}, \mathrm{pH}$ 7.6. After $1 \mathrm{~min}, 30 \mu \mathrm{g} \mathrm{ADH} \mathrm{mL}{ }^{-1}$ was added, the sample was incubated for $30 \mathrm{~min}$ and O.D. was determined at $340 \mathrm{~nm}$ in a POLARstar Omega. Ethanol is reported as $\mu \mathrm{mol}$ ethanol (mg prot) ${ }^{-1}$ (Araiza-Olivera et al. 2013).

\section{ATP concentration}

ATP was measured in cytoplasm extracts resuspended to $0.025 \mathrm{mg}$ protein in $0.15 \mathrm{~mL}$ reaction buffer $(20 \mathrm{mM}$ $\mathrm{KH}_{2} \mathrm{PO}_{4}, 40 \mathrm{mM} \mathrm{Na} \mathrm{HPO}_{4}, 80 \mathrm{mM} \mathrm{NaCl}, 1 \mathrm{mM}$ $\left.\mathrm{MgSO}_{4}\right)$. An ATP calibration curve was prepared freshly each day using lyophilized luciferase (Sigma-Aldrich). Luciferase was prepared following instructions by the provider and $0.02 \mathrm{~mL}$ was added to each sample in a 96-well microplate. Bioluminescence was detected in a POLARstar Omega luminometer (BGM LABTECH, Offenburg, Germany). [ATP] was reported as $\mu$ mol

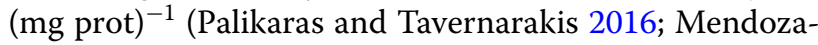
Hoffmann et al. 2018). 


\section{Susceptibility to hydrogen peroxide-mediated damage}

The effect of $\left[\mathrm{H}_{2} \mathrm{O}_{2}\right]$ on the viability of $S$. epidermidis was determined as previously reported (Macvanin and Hughes 2010). Briefly, cells were adjusted to an O.D. $=0.1(600 \mathrm{~nm})$ and then $\mathrm{H}_{2} \mathrm{O}_{2}(0$ to $25 \mathrm{mM}$ as indicated) was added to the reaction mixture. After $30 \mathrm{~min}$, serial dilution of the cultures was performed in $0.9 \% \mathrm{NaCl}$ and $10 \mu \mathrm{L}$ of the $1: 1000$ diluted sample was plated in LB, $2 \%$ glucose agar plates and incubated $24 \mathrm{~h}$ at $37^{\circ} \mathrm{C}$. Colony forming units $(\mathrm{CFU}) \mathrm{mL}^{-1}$ were counted. The sample taken before $\mathrm{H}_{2} \mathrm{O}_{2}$ addition was assigned as $100 \%$. The average of three experiments is shown with SD. ANOVA test and Tukey's multiple comparison-test were used. Significance was " $P<0.0001$.

\section{Biofilm formation and detection}

Biofilm generation was measured in sterile Costar 96-well polystyrene plates as previously reported (Calà et al. 2015; Uribe-Alvarez et al. 2016). Briefly, in each well, $0.4 \%$ crystal violet in $33 \%$ glacial acetic acid was mixed with the indicated, inhibitors sodium cyanide $(\mathrm{NaCN})(100 \mu \mathrm{M})$, butane-1,4-bisphosphate (B1,4BP) $(1 \mathrm{mM})$ or, carbonyl cyanide $m$-chlorophenyl hydrazone (CCCP) $(0.1,0.5$, or $1 \mu \mathrm{M}$, as indicated). Then bacteria were added to O.D. 0.02. Final volume $200 \mu \mathrm{L}$. The plate was incubated $24 \mathrm{~h}$ at $37^{\circ} \mathrm{C}$ with $5 \%$ $\mathrm{CO}_{2}$. After incubation, wells were washed twice with $200 \mu \mathrm{L}$ phosphate-buffered saline (PBS) to remove nonadherent bacteria. Plates were dried for $1 \mathrm{~h}$ at $60{ }^{\circ} \mathrm{C}$, stained with $0.4 \%$ crystal violet for $10 \mathrm{~min}$ and washed under running tap water to remove excess stain. Absorbance (492 nm) was measured using a microplate reader (Polar Star Omega, BMG Labtech). Each sample was tested in three independent triplicate experiments and compared against the non-treated control using one-way variance analysis (ANOVA) plus Dunnett's post hoc test.

\section{Results}

Oxygen is among the most important factors driving evolution (Lane 2002). Its partial reduction products, the reactive oxygen species (ROS) destroy nucleic acids, proteins and membranes (Ezraty et al. 2017). Thus, to profit from its remarkable electron acceptor properties, organisms have to deal carefully with the dangerous oxygen molecule (Lane 2002; Rosas-Lemus et al. 2016b). $S$. epidermidis lives in hypoxic/anoxic environments, although it can adapt to high $\left[\mathrm{O}_{2}\right]$. In order to follow the metabolic adaptation of $S$. epidermidis it was cultivated at different $\left[\mathrm{O}_{2}\right]$. After $24 \mathrm{~h}$ under aerobic conditions biomass yield was $8.58 \mathrm{~g} / \mathrm{L}$, three times higher than under microaerobiosis, $2.11 \mathrm{~g} / \mathrm{L}$ or anaerobiosis, $1.75 \mathrm{~g} / \mathrm{L}$.

In order to further explore the basis for biomass yield variations at different $\left[\mathrm{O}_{2}\right]$, the activity of the respiratory chain from $S$. epidermidis grown at different $\left[\mathrm{O}_{2}\right]$ was measured (Fig. 1). As expected from previous respiratory chain protein expression results (UribeAlvarez et al. 2016), the ability of cells to consume oxygen was proportional to $\left[\mathrm{O}_{2}\right]$ in the growth medium. In aerobic conditions and in the presence of lactate the rate of oxygen consumption was 70 natgO $(\mathrm{mg} \text { prot. } \mathrm{min})^{-1}$, at least five times higher than in microaerobic media, where the rate was 5 natgO (mg prot. min $)^{-1}$ or in those grown under anaerobic conditions, where it was negligible (Fig. 1). Under normoxia the best respiratory fuel was lactate, which was oxidized around three times as fast as glucose or ethanol (Fig. 1).

In S. epidermidis respiratory chain activities correlated with growth rates. However, it was reasoned that in hypoxia glycolysis may constitute an important source of energy (Somerville and Proctor 2009). Furthermore, as S. epidermidis, normally lives at low $\left[\mathrm{O}_{2}\right]$, fermentation may be the preferred energy-yielding pathway in this bacterium. To test this, S. epidermidis was grown at different $\left[\mathrm{O}_{2}\right]$ and ethanol production from either glucose (Fig. 2a) or glycerol (Fig. 2b) was measured at 2.5, 5 and $10 \mathrm{~min}$ of incubation. Both substrates were equally efficient. However, at different $\left[\mathrm{O}_{2}\right]$ large variations in the rate of fermentation were observed: bacteria from anaerobic media were the most active, (Fig. 2), suggesting that fermentation increases as $\left[\mathrm{O}_{2}\right]$ decreases.

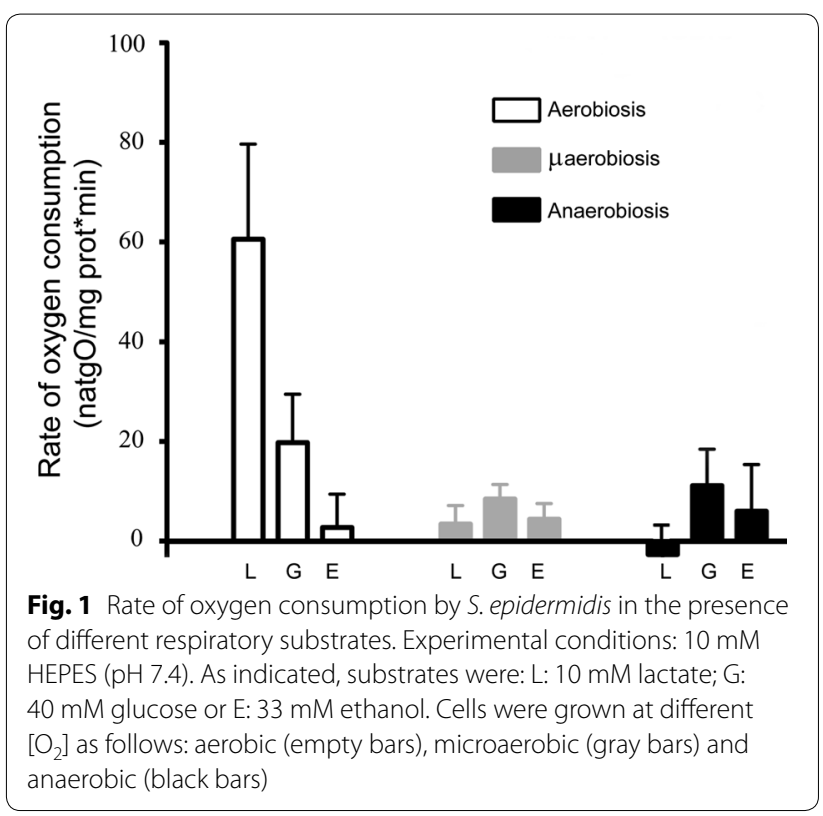




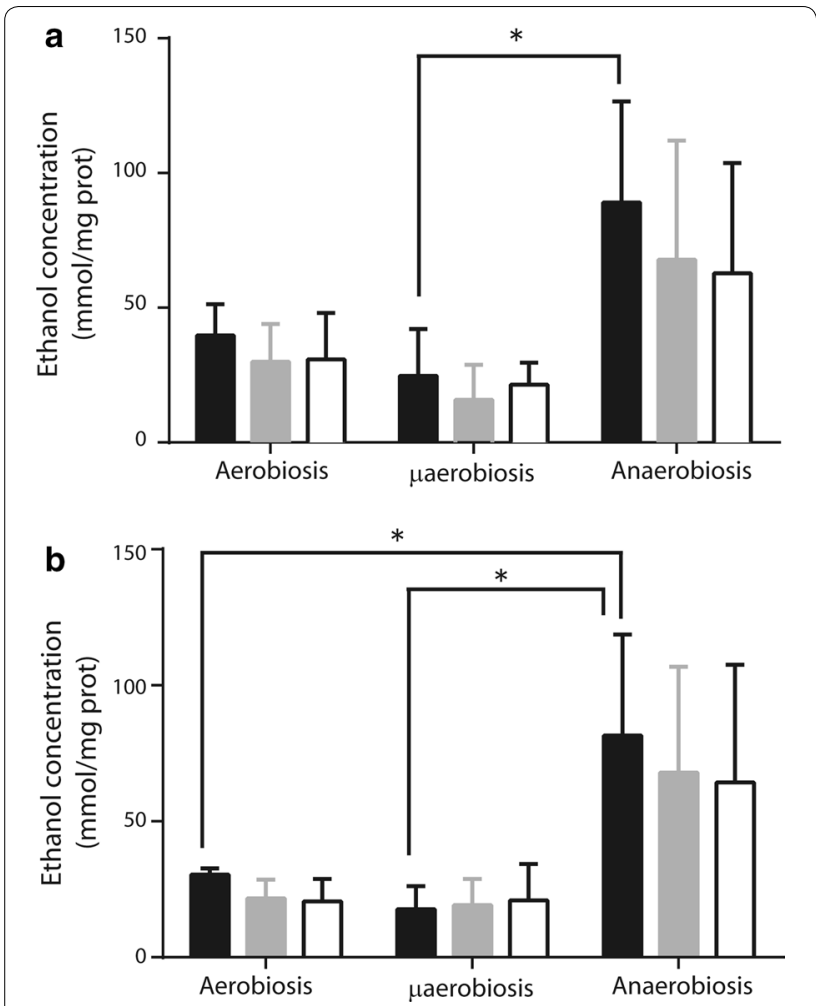

Fig. 2 Fermentation by S. epidermidis grown at different $\left[\mathrm{O}_{2}\right]$. Cytoplasmic extracts were obtained from $\mathrm{S}$. epidermidis grown under aerobic, microaerobic or anaerobic conditions. Fermentation by cell cytoplasmic extracts $\left(0.5 \mathrm{mg}\right.$ prot. $\left.\mathrm{mL}^{-1}\right)$ was measured using a $20 \mathrm{mM}$ glucose or b $20 \mathrm{mM}$ glycerol. Samples were incubated at $30^{\circ} \mathrm{C}$ for: $2.5 \mathrm{~min}$ (black columns), $5 \mathrm{~min}$ (gray columns) or $10 \mathrm{~min}$ (white columns). Results are reported as $\mu \mathrm{mol}$ ethanol per mg protein. Tukey's comparison test was used to determine significant differences $\left({ }^{*} P<0.05\right)$

In S. epidermidis, increasing $\left[\mathrm{O}_{2}\right]$ increased the rate of oxygen consumption while fermentation was inhibited. To determine which of these pathways produced more energy, the concentration of ATP ([ATP]) was measured in S. epidermidis grown under normoxia, hypoxia or anoxia (Fig. 3). Contrary to what we expected from the low growth rate and the slow respiratory activity observed, in hypoxia- and anoxia-grown cells, [ATP] was higher than in normoxia as aerobiosis, [ATP] increased roughly five times in hypoxia and three times in anoxia as compared to normoxia (Fig. 3).

In $S$. aureus a deficient respiratory chain confers resistance to $\mathrm{H}_{2} \mathrm{O}_{2}$ toxicity (Painter et al. 2017), suggesting that anaerobiosis-adapted cells resist oxidative stress better. Thus, we decided to test $S$. epidermidis grown at different $\left[\mathrm{O}_{2}\right]$ for its sensitivity to $\mathrm{H}_{2} \mathrm{O}_{2}$ (Fig. 4) (Lobritz et al. 2015). Even at the lowest concentrations of $\mathrm{H}_{2} \mathrm{O}_{2}$ we used $(0.5 \mathrm{mM})$, viability decreased in all cells. Aerobicgrown cells exhibited the poorest survival rates, while

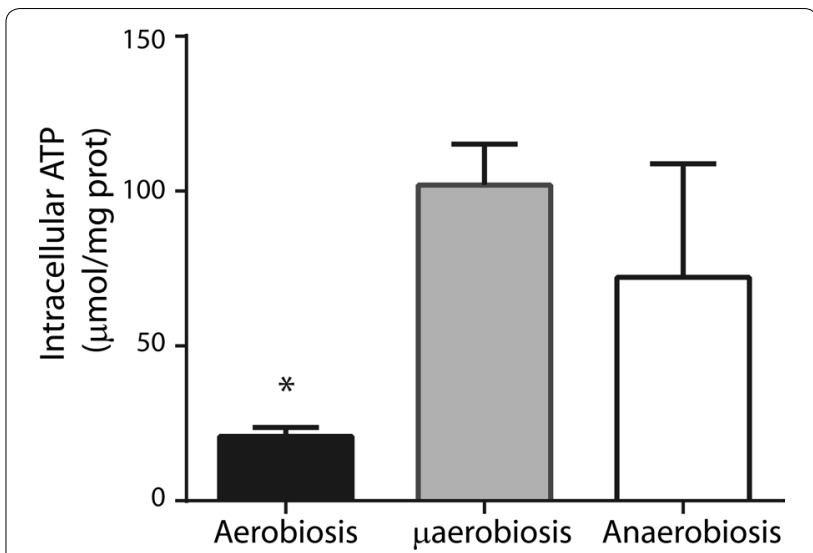

Fig. 3 Intracellular ATP concentrations in S. epidermidis grown at different $\left[\mathrm{O}_{2}\right]$. Cells were grown at different $\left[\mathrm{O}_{2}\right]$ in LB plus glucose. Cytoplasmic extracts were obtained from each of these cultures and used to measure intracellular ATP. ATP concentration was estimated using luciferase and interpolating into a standard curve (see "Materials and methods"). The average of three experiments is shown with SD. * indicates significant difference $P<0.05$

cells grown under anaerobiosis survived best, such that even at the highest $\mathrm{H}_{2} \mathrm{O}_{2}$ concentration tested $(25 \mathrm{mM}$ $\mathrm{H}_{2} \mathrm{O}_{2}$ ) a small amount of viable cells was detected (Fig. 4). The increase in sensitivity to ROS observed in aerobically grown $S$. epidermidis was probably due to increased expression of the redox enzymes in the respiratory chain (Uribe-Alvarez et al. 2016). These redox enzymes contain different coenzymes and prosthetic groups, which normally become free radicals during their catalytic cycle (Quinlan et al. 2013; Rosas-Lemus et al. 2016b). Thus, as reported for S. aureus (Painter et al. 2017) at high $\left[\mathrm{O}_{2}\right] S$. epidermidis expressed an active respiratory chain and its sensitivity to $\mathrm{H}_{2} \mathrm{O}_{2}$ increased.

The highest [ATP] was detected in cells grown at low $\left[\mathrm{O}_{2}\right]$, which exhibited a slow growth rate. This seemingly contradictory situation may be explained by proposing that when $S$. epidermidis finds a low $\left[\mathrm{O}_{2}\right]$, which resembles that found in its normal niche, it makes an effort to attach itself to a surface, redirecting its energy use from growth to produce polysaccharides and proteins for biofilm generation (Beenken et al. 2004; Lewis 2007). To analyze whether biofilm was dependent on [ATP], S. epidermidis was grown under hypoxia and in the presence and absence of different metabolic inhibitors. In hypoxic grown-cells both oxidative phosphorylation and fermentation are active. It was observed that cells incubated in the presence of the respiratory chain inhibitor cyanide or the glycolytic inhibitor 1,4-bisphosphobutane, formed smaller biofilms than the control and that addition of both inhibitors led to even less biofilms (Fig. 5a). This would suggest that biofilm 


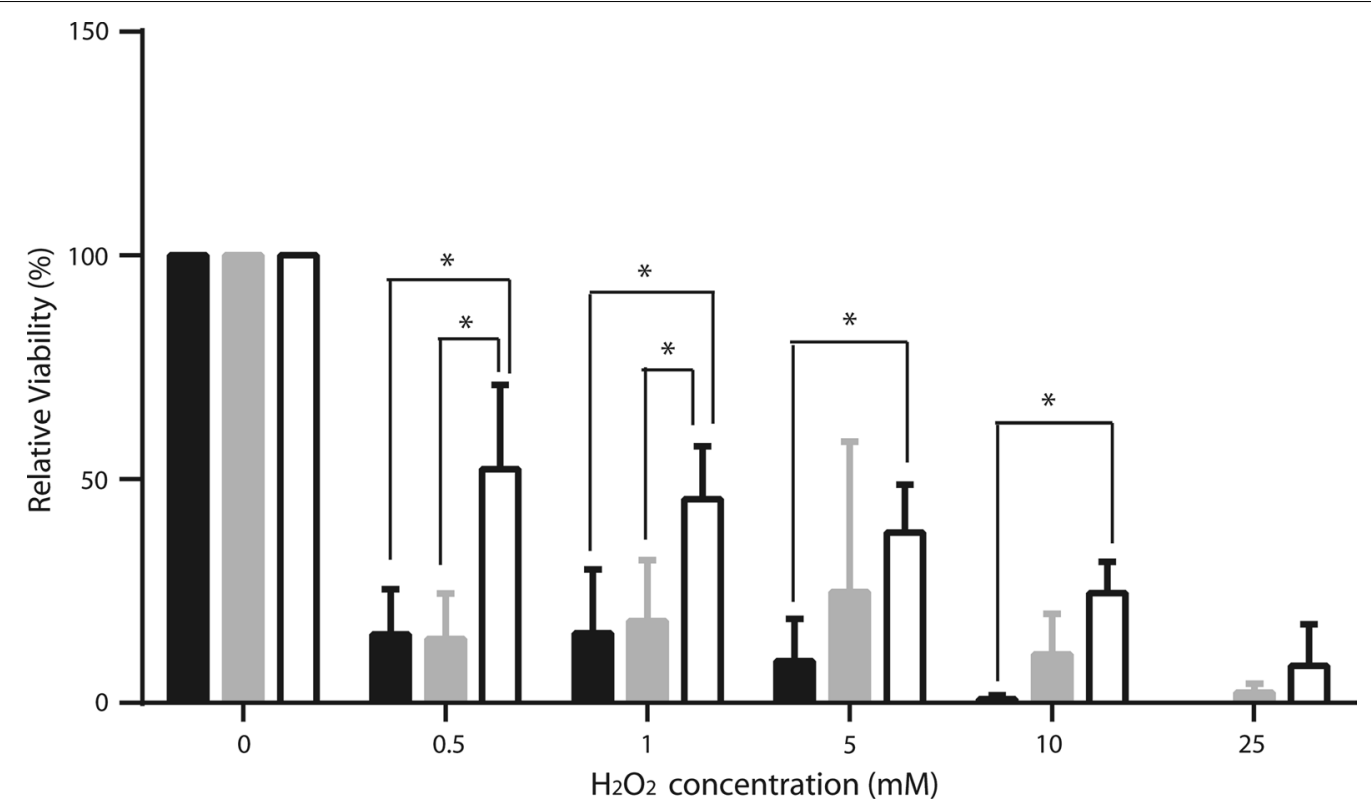

Fig. $4 \mathrm{H}_{2} \mathrm{O}_{2}$ effect on cellular viability. S. epidermidis susceptibility to hydrogen peroxide was determined using $0,0.5,1,5,10$ or $25 \mathrm{mM} \mathrm{H}_{2} \mathrm{O}_{2}$ in each group: aerobiosis (black bar), microaerobiosis (gray bar) or anaerobiosis (white bar). After 30 min of incubation with $\mathrm{H}_{2} \mathrm{O}_{2}$, the samples were diluted 1:1000, $10 \mu \mathrm{L}$ were taken and plated in LB plus $2 \%$ glucose-agar. CFU/mL were counted. Samples without treatment were assigned as $100 \%$ viable cells. The average of three experiments is shown with SD. Significance ${ }^{*} P<0.0001$
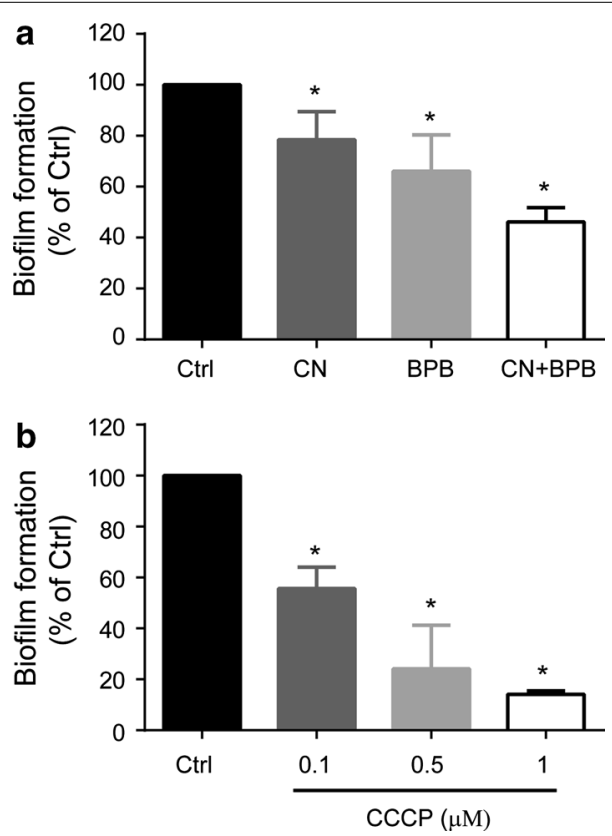

Fig. 5 In vitro biofilm inhibition assay. S. epidermidis was grown under microaerobic conditions. a Different metabolic inhibitors were added as indicated: $100 \mu \mathrm{M} \mathrm{NaCN}, 1$ mM B1,4BP or both inhibitors. b Different concentrations of the uncoupler CCCP $(0.5,1.0$ and $1.5 \mu \mathrm{M})$ were added to deplete ATP. After $24 \mathrm{~h}$ of incubation biofilm generation was evaluated by measuring the absorbance at $492 \mathrm{~nm}$ with a microplate reader. Each sample was compared with the control (without additions). Statistics were applied using ANOVA and Dunnett's post hoc test. Significance ${ }^{*} P<0.0001$ formation activity is proportional to [ATP]. In addition, the uncoupler CCCP was used at concentrations below those where it killed cells (Result not-shown), observing that biofilm generation decreased further as uncoupler concentration increased (Fig. 5b). These results suggest that, regardless of its source, in S. epidermidis high [ATP] is needed to form biofilms.

\section{Discussion}

Antibiotic-resistant strains of $S$. epidermidis are increasingly found in nosocomial infections (Chabi and Momtaz 2019). Implant removal due to S. epidermidis biofilm colonization is also quite frequent (Gristina 1987; Raad et al. 1998). S. epidermidis is frequently found in coagulase-negative staphylococci-caused prosthetic valve infective endocarditis cases (Mack et al. 2013), in 30-43\% implant infections (Zimmerli et al. 2004) and in 50-70\% catheter-related infections (von Eiff et al. 2002). Understanding the physiology of the bacterium is a must in order to design new treatment and prevention methods (Uribe-Alvarez et al. 2016). In biofilms, S. epidermidis cells are protected from the host. Thus, it is most important to analyse the association and specialization processes of the cells involved in the genesis of biofilms.

Diverse facultative bacteria adapt to wide $\left[\mathrm{O}_{2}\right]$, differentially expressing redox enzymes in its respiratory chain. S. epidermidis does express different enzymes 
at varying $\left[\mathrm{O}_{2}\right]$ (Uribe-Alvarez et al. 2016). Aerobic metabolism enabled cells to grow more (Baez and Shiloach 2014). Still, enhanced growth resulted in higher sensitivity to $\mathrm{H}_{2} \mathrm{O}_{2}$, suggesting that high contents of redox enzymes make cells vulnerable to ROS. Indeed, when grown at high $\left[\mathrm{O}_{2}\right]$, sensitivity to ROS is enhanced in S. aureus and Enterococcus faecalis, while their mutant counterparts, lacking an efficient respiratory chain resist ROS better (Painter et al. 2017).

When exposing S. epidermidis grown in different $\left[\mathrm{O}_{2}\right]$ to oxygen peroxide, we observed a similar phenomenon: cells grown in hypoxic or anoxic environments, which exhibited low respiratory rates were more resistant to oxygen peroxide (Fig. 4). Thus, as in S. aureus, the lack of an efficient respiratory chain in S. epidermidis enabled cells to survive ROS. This is probably useful when bacteria detached from a biofilm reach other tissues where they may be confronted with the oxidative burst generated by the immune system (Jensen et al. 1992).

The rate of oxygen consumption in aerobic grown cells was highest when lactate was the substrate. This is probably due to the direct donation of electrons to the menaquinone pool by lactate dehydrogenase (Götz and Mayer 2013; Kane et al. 2016). The slower rates observed for alcohol, may be due to an additional step as alcohol dehydrogenase electrons are first donated to Ndi2 (Artzatbanov and Petrov 1990). The rate of respiration was also slow for glucose, probably for the same reason, as intermediaries have to undergo many reactions before releasing electrons to the respiratory chain (Ferreira et al. 2013). In contrast, under anaerobiosis, lactate-dependent oxygen consumption disappeared completely while a small rate of glucose-dependent oxygen consumption was still present. In contrast, in $S$. aureus increased lactate dehydrogenase expression anaerobiosis has been reported (Fuchs et al. 2007).

The normal habitat for $S$. epidermidis is the microaerobic environment found in different epidermic and dermic layers (Peyssonnaux et al. 2008). One strategy S. epidermidis uses when confronted with high $\left[\mathrm{O}_{2}\right]$ is the differential expression of a diverse number of redox enzymes in the respiratory chain. Reports indicate that when microaerophilic or anaerophilic bacteria find a suitable environment, they react manufacturing proteins and polysaccharides that enable them to form biofilms and attach to surfaces at low $\left[\mathrm{O}_{2}\right]$. Avoiding high $\left[\mathrm{O}_{2}\right]$ involves both, anchoring in low oxygen environments and building biofilms as barriers against penetration of ROS or toxic substances (Palikaras and Tavernarakis 2016). Metabolic adaptation has also been reported for Neisseria gonorrhoeae, when it is stimulated to form biofilms. A proteomic analysis of $N$. gonorrhoeae biofilms evidenced up-regulation of proteins involved in anaerobic metabolism such as glycolysis and TCA cycle plus increased expression of those proteins involved in biofilm generation like pilus-associated proteins (Phillips et al. 2012). In addition, some oxidative stress genes are required for normal biofilm formation in $N$. gonorrhoeae (Falsetta et al. 2011).

The increase in ATP prior to biofilm formation has been reported in others bacterium. Bacillus brevis and Escherichia coli react to substrate depletion by adhering to glass surfaces and at the same time increase [ATP] two to fivefold as compared to planktonic cells (Hong and Brown 2009). So, the conditions where bacteria need to make biofilms promote saving ATP even at the expense of the growth rate. ATP is most likely needed to synthesize the extracellular proteins and the polysaccharide fibers that anchor cells to surfaces and to each other. Inhibiting ATP production in micro- or anaerobic conditions by adding cyanide or 1,4-bisphosphobutane resulted in a reduced biofilm formation (Fig. 5). This phenomenon is also observed when treating S. epidermidis with the nitrate reductase inhibitor methylamine in anaerobic conditions (Uribe-Alvarez et al. 2016). In contrast, in aerobiosis cyanide promotes biofilm formation (UribeAlvarez et al. 2016).

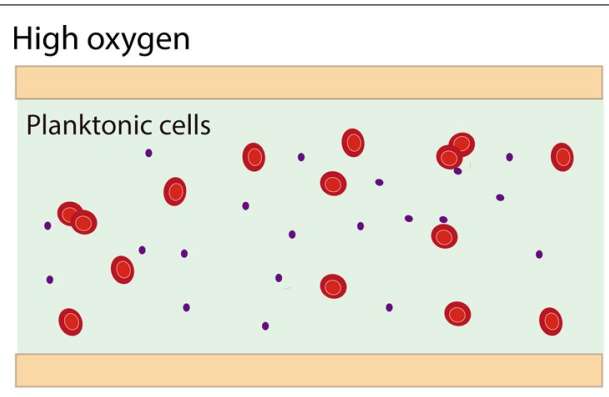

Low oxgen/High Energy

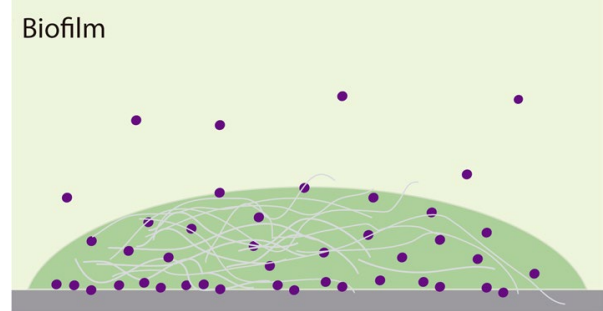

Fig. 6 Cartoon depicting the shift that Staphylococcus epidermidis makes when $\left[\mathrm{O}_{2}\right]$ decreases in the growth medium. When high oxygen concentrations are found in the medium, S. epidermidis are planktonic cells and flow with the blood (top). In contrast, under micro- or anaerobic conditions cells shift to a fermentative metabolism and accumulate ATP adhering to a suitable surface (e.g. epithelia, catheters, artificial valves) and eventually forming a biofilm. In this state the cells exhibit more resistance to $\mathrm{H}_{2} \mathrm{O}_{2}$ mediated damage. Excess ATP is probably used to produce adhesion proteins and poly- $\mathrm{N}$-acetylglucosamine (gray fibers in the illustration) (bottom) 
Even when facultative bacteria such as $S$. epidermidis survive at high $\left[\mathrm{O}_{2}\right]$, their habitat in the skin is hypoxic to anoxic. While they survive in aerobic environments their susceptibility to ROS-mediated damage and possibly to attack by macrophages increases. They thus present an oxygen avoidance behavior, anchoring and associating in hypoxic environments (Fig. 6). Learning how avoidance works in S. epidermidis and other bacteria would impact both the physiologic and therapeutic field.

Aiming to understand such rise in ATP, we found that other bacteria, e.g. Bacillus brevis and Escherichia coli, react to substrate depletion by adhering to glass surfaces and at the same time increase [ATP] two- to fivefold in comparison to planktonic cells (Hong and Brown 2009). In this regard, it has been reported that hypoxic stimuli induce biofilm formation in S. epidermidis (UribeAlvarez et al. 2016).

\section{Acknowledgements}

Partially funded by UNAM/DGAPA/PAPIIT grant IN203018 to SUC and CONACYT 241670 grant to AMA. UPD (MsSc) and EES (PhD) are graduate students in the Biochemistry Program at UNAM. LMG is in the Biomedical $\mathrm{PhD}$ program at UNAM. OMR is a graduate student at CIAD. UPD, LMG and OMR are CONACYT fellows. CUA present address: Fox-Chase Cancer Center, Philadelphia, PA. Technical help from Ramón Méndez-Franco is acknowledged.

\section{Authors' contributions}

UPD, participated in all experiments and in discussions helping to write and edit the manuscript. CUA contributed to the original idea, she was the first author of the previous paper, participated in oxymetry experiments and in discussions helping to write and edit the manuscript. LMG participated in oxygen-consumption experiments and discussions on the manuscript. EES, participated in fermentation experiments and in discussions. OMR participated in the experiments performed both at CIAD and at UNAM and in discussions. AMA contributed with early ideas and designed some protocols, she provided reagents and facilities at CIAD and edited the manuscript. NCF taught graduate students the techniques involved in each experiment, supervising experimental work and protocols. SUC helped develop the original idea, designed the project, helped in technique application and wrote the manuscript. He provided facilities and found funding. Participated in lab discussions. All authors read and approved the final manuscript.

\section{Ethics approval and consent to participate}

This article does not contain any studies with human participants or animals performed by any of the authors.

\section{Competing interests}

The authors declare that they have no competing interests.

\section{Author details}

${ }^{1}$ Department of Genetics and Molecular Biology, Instituto de Fisiología Celular, Universidad Nacional Autónoma de México (UNAM), Mexico City, Mexico. ${ }^{2}$ Centro de Investigación y Desarrollo en Alimentos (CIAD), Hermosillo, Sonora, Mexico.

Received: 28 January 2020 Accepted: 31 January 2020

Published online: 11 February 2020

\section{References}

Araiza-Olivera D, Chiquete-Felix N, Rosas-Lemus M, Sampedro JG, Peña A, Mujica A, Uribe-Carvajal S (2013) A glycolytic metabolon in Saccharomyces cerevisiae is stabilized by F-actin. FEBS J 280:3887-3905. https://doi.org/10.1111/febs.12387
Artzatbanov VYu, Petrov W (1990) Branched respiratory chain in aerobically grown Staphylococcus aureus - oxidation of ethanol by cells and protoplasts. Arch Microbiol 153:580-584

Baez A, Shiloach J (2014) Effect of elevated oxygen concentration on bacteria, yeasts, and cells propagated for production of biological compounds. Microb Cell Fact 13:181. https://doi.org/10.1186/s12934-014-0181-5

Beck S, Sehl C, Voortmann S, Verhasselt HL, Edwards MJ, Buer J, Hasenberg M, Gulbins E, Becker KA (2019) Sphingosine is able to prevent and eliminate Staphylococcus epidermidis biofilm formation on different orthopedic implant materials in vitro. J Mol Med. https://doi.org/10.1007/s0010 9-019-01858-x

Beenken KE, Dunman PM, McAleese F, Macapagal D, Murphy E, Projan SJ, Blevins JS, Smeltzer MS (2004) global gene expression in Staphylococcus aureus biofilms. J Bacteriol 186:4665-4684. https://doi.org/10.1128/ JB.186.14.4665-4684.2004

Berg RD (1996) The indigenous gastrointestinal microflora. Trends Microbiol 4:430-435. https://doi.org/10.1016/0966-842X(96)10057-3

Bradford MM (1976) A rapid and sensitive method for the quantitation of microgram quantities of protein utilizing the principle of protein-dye binding. Anal Biochem 72:248-254

Büttner H, Mack D, Rohde H (2015) Structural basis of Staphylococcus epidermidis biofilm formation: mechanisms and molecular interactions. Front Cell Infect Microbiol 5:14. https://doi.org/10.3389/fcimb.2015.00014

Calà C, Amodio E, Di Carlo E, Virruso R, Fasciana T, Giammanco A (2015) Biofilm production in Staphylococcus epidermidis strains, isolated from the skin of hospitalized patients: genetic and phenotypic characteristics. N Microbiol 38:521-529

Chabi R, Momtaz H (2019) Virulence factors and antibiotic resistance properties of the Staphylococcus epidermidis strains isolated from hospital infections in Ahvaz, Iran. Trop Med Health 47:56. https://doi.org/10.1186/ s41182-019-0180-7

Cogen AL, Yamasaki K, Sanchez KM, Dorschner RA, Lai Y, MacLeod DT, Torpey JW, Otto M, Nizet V, Kim JE, Gallo RL (2010) Selective antimicrobial action is provided by phenol-soluble modulins derived from Staphylococcus epidermidis, a normal resident of the skin. J Invest Dermatol 130(1):192-200

Cotter JJ, O'Gara JP, Mack D, Casey E (2009) Oxygen-mediated regulation of biofilm development is controlled by the alternative sigma factor sigma(B) in Staphylococcus epidermidis. Appl Environ Microbiol 75:261264. https://doi.org/10.1128/AEM.00261-08

Ezraty B, Gennaris A, Barras F, Collet J-F (2017) The gain of single electrons by oxygen $\left(\mathrm{O}^{2}\right)$ generates partially reduced reactive oxygen species (ROS), including superoxide anions ( $\mathrm{O}^{2}$. - . Nat Publ Gr. https://doi.org/10.1038/ nrmicro.2017.26

Falsetta ML, Steichen CT, McEwan AG, Cho C, Ketterer M, Shao J, Hunt J, Jennings MP, Apicella MA (2011) The composition and metabolic phenotype of Neisseria gonorrhoeae biofilms. Front Microbiol 2:75. https ://doi.org/10.3389/fmicb.2011.00075

Fang FC, Frawley ER, Tapscott T, Vázquez-Torres A (2016) Bacterial stress responses during host infection. Cell Host Microbe 20:133-143. https:// doi.org/10.1016/j.chom.2016.07.009

Ferreira MT, Manso AS, Gaspar P, Pinho MG, Neves AR (2013) Effect of oxygen on glucose metabolism: utilization of lactate in Staphylococcus aureus as revealed by in vivo NMR studies. PLoS ONE 8:e58277. https://doi. org/10.1371/journal.pone.0058277

Fey PD, Olson ME (2010) Current concepts in biofilm formation of Staphylococcus epidermidis. Future Microbiol 5:917-933. https://doi. org/10.2217/fmb.10.56

Foster J, Ganatra M, Kamal I, Ware J, Makarova K, Ivanova N, Bhattacharyya A, Kapatral V, Kumar S, Posfai J, Vincze T, Ingram J, Moran L, Lapidus A, Omelchenko M, Kyrpides N, Ghedin E, Wang S, Goltsman E, Joukov V, Ostrovskaya O, Tsukerman K, Mazur M, Comb D, Koonin E, Slatko B (2005) The Wolbachia genome of Brugia malayi: endosymbiont evolution within a human pathogenic nematode. PLoS Biol 3:e121. https://doi. org/10.1371/journal.pbio.0030121

Fuchs S, Pané-Farré J, Kohler C, Hecker M, Engelmann S (2007) Anaerobic gene expression in Staphylococcus aureus. J Bacteriol 189:4275-4289. https:// doi.org/10.1128/JB.00081-07

Gornall AG, Bardawill CJ, David MM (1949) Determination of serum proteins by means of the biuret reaction. J Biol Chem 177:751-766 
Götz F, Mayer S (2013) Both terminal oxidases contribute to fitness and virulence during organ-specific Staphylococcus aureus colonization. MBio 4:e00976-13. https://doi.org/10.1128/mBio.00976-13

Grice EA, Segre JA (2011) The skin microbiome. Nat Rev Microbiol 9:244-253. https://doi.org/10.1038/nrmicro2537

Gristina AG (1987) Biomaterial-centered infection: microbial adhesion versus tissue integration. Science 237:1588-1595. https://doi.org/10.1126/scien ce.3629258

Hartman FC, Barker R (1965) An exploration of the active site of aldolase using structural analogs of fructose diphosphate ${ }^{*}$. Biochemistry 4:1068-1075. https://doi.org/10.1021/bi00882a014

Hong Y, Brown DG (2009) Variation in bacterial ATP level and proton motive force due to adhesion to a solid surface. Appl Environ Microbiol 75:23462353. https://doi.org/10.1128/AEM.02671-08

Iwase T, Uehara Y, Shinji H, Tajima A, Seo H, Takada K, Agata T, Mizunoe Y (2010) Staphylococcus epidermidis Esp inhibits Staphylococcus aureus biofilm formation and nasal colonization. Nature 465:346-349. https://doi. org/10.1038/nature09074

Jensen ET, Kharazmi A, Høiby N, Costerton JW (1992) Some bacterial parameters influencing the neutrophil oxidative burst response to Pseudomonas aeruginosa biofilms. APMIS 100:727-733. https://doi. org/10.1111/j.1699-0463.1992.tb03991.x

Kane AL, Brutinel ED, Joo H, Maysonet R, VanDrisse CM, Kotloski NJ, Gralnick JA (2016) Formate metabolism in Shewanella oneidensis generates proton motive force and prevents growth without an electron acceptor. J Bacteriol 198:1337-1346. https://doi.org/10.1128/JB.00927-15

Lane N (2002) Oxygen: the molecule that made the world. Oxford University Press, Oxford

Leid JG (2009) Bacterial biofilms resist key host defenses. Microbe 4:66-70

Lewis K (2007) Persister cells, dormancy and infectious disease. Nat Rev Microbiol 5:48-56. https://doi.org/10.1038/nrmicro1557

Lobritz MA, Belenky P, Porter CBM, Gutierrez A, Yang JH, Schwarz EG, Dwyer DJ, Khalil AS, Collins JJ (2015) Antibiotic efficacy is linked to bacterial cellular respiration. Proc Natl Acad Sci USA 112:8173-8180. https://doi. org/10.1073/pnas.1509743112

Mack D, Davies AP, Harris LG, Jeeves R, Pascoe B, Knobloch JK-M, Rohde H, Wilkinson TS (2013) Staphylococcus epidermidis in biomaterial-associated infections. Biomaterials associated infection. Springer, New York, pp 25-56

Macvanin M, Hughes D (2010) Assays of sensitivity of antibiotic-resistant bacteria to hydrogen peroxide and measurement of catalase activity. Methods in molecular biology. Humana Press, Clifton, pp 95-103

Mendoza-Hoffmann F, Pérez-Oseguera Á, Cevallos MÁ, Zarco-Zavala M, Ortega R, Peña-Segura C, Espinoza-Simón E, Uribe-Carvajal S, García-Trejo JJ (2018) The biological role of the $\zeta$ subunit as unidirectional inhibitor of the F1FO-ATPase of Paracoccus denitrificans. Cell Rep 22:1067-1078. https ://doi.org/10.1016/j.celrep.2017.12.106

Painter KL, Hall A, Ha KP, Edwards AM (2017) The electron transport chain sensitizes Staphylococcus aureus and Enterococcus faecalis to the oxidative burst. Infect Immun. https://doi.org/10.1128/IAl.00659-17

Palikaras K, Tavernarakis N (2016) Intracellular assessment of ATP levels in Caenorhabditis elegans. Bio-Protocol. https://doi.org/10.21769/BioPr otoc.2048

Peyssonnaux C, Boutin AT, Zinkernagel AS, Datta V, Nizet V, Johnson RS (2008) Critical role of HIF-1 a in keratinocyte defense against bacterial infection. J Invest Dermatol 128:1964-1968. https://doi.org/10.1038/JID.2008.27
Phillips NJ, Steichen CT, Schilling B, Post DMB, Niles RK, Bair TB, Falsetta ML, Apicella MA, Gibson BW (2012) Proteomic analysis of Neisseria gonorrhoeae biofilms shows shift to anaerobic respiration and changes in nutrient transport and outermembrane proteins. PLoS ONE 7:e38303. https://doi.org/10.1371/journal.pone.0038303

Pilz M, Staats K, Tobudic S, Assadian O, Presterl E, Windhager R, Holinka J (2019) Zirconium nitride coating reduced Staphylococcus epidermidis biofilm formation on orthopaedic implant surfaces: an in vitro study. Clin Orthop Relat Res 477:461-466. https://doi.org/10.1097/CORR.0000000000000568

Quinlan CL, Perevoshchikova IV, Hey-Mogensen M, Orr AL, Brand MD (2013) Sites of reactive oxygen species generation by mitochondria oxidizing different substrates. Redox Biol 1:304-312. https://doi.org/10.1016/j.redox .2013.04.005

Raad I, Alrahwan A, Rolston K (1998) Staphylococcus epidermidis: emerging resistance and need for alternative agents. Clin Infect Dis 26:1182-1187. https://doi.org/10.1086/520285

Rabin N, Zheng Y, Opoku-Temeng C, Du Y, Bonsu E, Sintim HO (2015) Biofilm formation mechanisms and targets for developing antibiofilm agents. Fut Med Chem 7:493-512

Rosas-Lemus M, Chiquete-Félix N, Ruíz-Pérez K, Rigoulet M, Devin A, Hernández-Rodríguez M, Uribe-Carvajal S (2016a) Sensitivity of the mitochondrial unspecific channel of Saccharomyces cerevisiae to butane1,4-bisphosphate, a competitive inhibitor of fructose-1,6-bisphosphatealdolase. ChemistrySelect 1:2930-2934. https://doi.org/10.1002/ slct.201600303

Rosas-Lemus M, Uribe-Alvarez C, Contreras-Zentella M, Luévano-Martínez LA, Chiquete-Félix N, Morales-García NL, Simón EE, Muhlia-Almazán A Escamilla-Marván E, Uribe-Carvajal S (2016b) Oxygen: from toxic waste to optimal (toxic) fuel of life. Free radicals and diseases. Rijeka, InTech

Roujansky A, Martin M, Gomart C, Hulin A, Mounier R (2020) Multidrugresistant Staphylococcus epidermidis ventriculostomy-related infection successfully treated by intravenous ceftaroline after failure of daptomycin treatment. World Neurosurg. https://doi.org/10.1016/j.wneu.2020.01.013

Sender R, Fuchs S, Milo R (2016) Revised estimates for the number of human and bacteria cells in the body. PLoS Biol. https://doi.org/10.1371/journ al.pbio. 1002533

Somerville GA, Proctor RA (2009) At the crossroads of bacterial metabolism and virulence factor synthesis in Staphylococci. Microbiol Mol Biol Rev 73:233-248. https://doi.org/10.1128/MMBR.00005-09

Uribe-Alvarez C, Chiquete-Félix N, Contreras-Zentella M, Guerrero-Castillo S, Peña A, Uribe-Carvajal S (2016) Staphylococcus epidermidis: metabolic adaptation and biofilm formation in response to different oxygen concentrations. Pathog Dis 74:ftv111. https://doi.org/10.1093/femspd/ ftv111

von Eiff C, Peters G, Heilmann C (2002) Pathogenesis of infections due to coagulase-negative staphylococci. Lancet Infect Dis 2:677-685. https:// doi.org/10.1016/s1473-3099(02)00438-3

Zimmerli W, Trampuz A, Ochsner PE (2004) Prosthetic-joint infections. N Engl J Med 351:1645-1654. https://doi.org/10.1056/NEJMra040181

\section{Publisher's Note}

Springer Nature remains neutral with regard to jurisdictional claims in published maps and institutional affiliations. 